For est ry Sect or Ref or $m$ and Di st $r$ i but i onal Change of Nat ur al Resource Rent in I ndonesi a

\begin{tabular}{|c|c|}
\hline 権利 & $\begin{array}{l}\text { Copyr i ght s 日本貿易振興機構 (ジェトロ ) アジア } \\
\text { 経济研究所 / I nst i t ut e of Devel opi ng } \\
\text { Econom es, Japan Ext er nal Tr ade Organi zat i on } \\
\text { ( I DE- JETRO) ht t p: // www. i de. go.j p }\end{array}$ \\
\hline $\begin{array}{l}\text { j our nal or } \\
\text { publ i cat } i \text { on } t i t l e\end{array}$ & The Devel opi ng Economi es \\
\hline vol une & 43 \\
\hline nunber & 1 \\
\hline page $r$ ange & $149-170$ \\
\hline year & 2005-03 \\
\hline 出版者 & I nst i t ut e of Devel opi ng Economi es ( I DE- JETRO) \\
\hline URL & ht t p: //doi . or g/10. 20561/00028747 \\
\hline
\end{tabular}




\title{
FORESTRY SECTOR REFORM AND DISTRIBUTIONAL CHANGE OF NATURAL RESOURCE RENT IN INDONESIA
}

\author{
GAKU KATO \\ First version received April 2004; final version accepted June 2004
}

\begin{abstract}
After the collapse of the centralized Soeharto regime, deforestation caused by overlogging accelerated. To tackle this problem, an IMF/World Bank-led forestry sector reform program adopted a market-friendly approach involving the resumption of round wood exports and raising of the resource rent fee, with the aim to stop rent accumulation by plywood companies, which had enjoyed a supply of round wood at privileged prices. The Indonesian government, for its part, decentralized the forest concession management system to provide incentives for local governments and communities to carry out sustainable forest management. However, neither policy reform worked effectively. The round wood export ban was reimposed and the forest management system centralized again with cooperation from a newly funded industry-led institution. In the midst of the confusion surrounding the policy reversal, the gap between the price of round wood in international and domestic markets failed to contract, although rent allocations to plywood companies were reduced during 1998-2003. The rents were not collected properly by the government, but accumulated unexpectedly in the hands of players in the black market for round wood.
\end{abstract}

\section{INTRODUCTION}

$\mathrm{S}$

INCE the economic crisis and the collapse of the Soeharto regime in 1998, deforestation has taken place at a rapid pace in Indonesia. The World Bank has made the shocking forecast that Indonesia's lowland natural forests will disappear by 2010 unless effective measures are taken to stop the deforestation. ${ }^{1}$ It has been argued that the causes of the deforestation include over-logging, fires, transmigration, and the conversion of forests to agricultural land. However, since the crisis, the problem of illegal logging has gathered attention and the issue of governance for sustainable forest management has become a topic of discussion.

The arguments concerning governance for forest management can be put into the following four categories. One is the argument that the decentralization of power

1 According to Holmes (2000), the lowland natural forests will disappear in Sumatra by 2005 and in Kalimantan by 2010 . 
and the enactment of the 1999 Forestry Act caused the failure of centralized control, which in turn led to attempts to move control to cooperatives and communities, and that institutional confusion arose in the transition process (Casson 2001; Dermawan and Resosudarmo 2002; Kartodihardjo 2002; McCarthy 2000). A second is the politico-social analysis that the growth of poverty caused by the economic crisis and the deterioration of order in the police and military accompanying the collapse of the Soeharto regime had a negative impact on the ability to control smuggling and illegal logging, leading to lawlessness in logging (Dudley 2002; Obidzinski and Suramenggala 2000). A third is the political economy analysis, focusing on developmentalism and the supply-demand balance of round wood, which argues that the thoughtless industrial promotion policy targeting the plywood, pulp, and palm oil industries, without giving consideration to the supply ability of forestry resources, has been carried out in a form that favors the growth of the Chinese-origin business groups that were cronies of Soeharto, ignoring the sustainable management of forests (Ascher 1999, chap. 3; Barr 2001; Brown 1999, 2002b). A fourth argument focuses on the distortion of round wood prices in Indonesia, claiming that the export ban on round wood and the low level of logging concession fees and taxes created a gap between international and domestic prices, and that the price mechanism was no longer able to make adjustments for sustainable forest management. This argument was made by the International Monetary Fund (IMF) and the World Bank as they promoted forestry sector reform beginning in 1998. In order to make prices of round wood more appropriate, measures such as the resumption of round wood exports, the abolition of the plywood export cartel, and a reform of the logging concession system were taken under IMF control.

However, the price mechanism approach implemented under the initiative of the IMF and World Bank was unable to stop the rampant illegal logging and deforestation. Rather, the resumption of round wood exports confused the market, leading to an expansion of the illegal market, and resulting in the reinstitution of the ban on round wood exports. The institutional reform led by the Indonesian Ministry of Forestry, which was carried out along with the general trend toward the decentralization of power, also stalled and the program had to be reviewed. In this study, we will overview the institutional reform of the forestry industry since 1998 and analyze its outcome and effectiveness from the point of view of changes in the distribution of natural resource rents.

\section{ANALYTICAL FRAMEWORK: RENT AND INCENTIVES}

Although natural resources such as wood are renewable, unlike mineral resources, the marginal cost for obtaining the resources rises as their exploitation proceeds. As long as the marginal cost is lower than the price, in a situation akin to a monopoly, a profit larger than that obtained through ordinary market transactions arises. This 
profit is called a "rent." Since a rent is an additional profit that would not arise under completely free competition, it is considered to be economically inefficient. However, natural resources are common property, and price adjustments do not function. As a result, given free access to the resource, the marginal cost can easily be higher than the marginal revenue. Therefore, unlike a monopoly rent, the existence of a natural resource rent shows efficiency. Thus it becomes important to establish property rights over natural resources as a measure to resolve this problem of free access (Khan 2000).

The establishment of property rights means the creation of rents in an institutional way. The establishment of property rights, as shown by Coase, leads to efficiency. In this case, the existence of rents creates the initial conditions for investment in the forest resource sector, thus contributing to industrial development, and at the same time, providing incentives for forest concession holders to conduct sustainable forest management. However, the establishment of property rights does not necessarily mean the establishment of private property rights. There is an argument that when managing common goods such as natural resources, management by communities can provide better monitoring functions than the establishment of private property rights (Ostrom 1990). On the other hand, blanket ownership and control by the national government is more efficient in a centralized country where overall coordination is relatively smooth. Thus the question of who receives the rent determines its effectiveness as an incentive for sustainable forest management.

In Indonesia, forests are basically owned by the state, and the central government has responsibility for property right management. The government has given forest logging concessions to corporations and cooperatives, assigning them to manage the allocated area on its behalf, and obtaining income in return through levies such as logging concession fees and taxes. If the government raises the fees and taxes to a higher level than necessary, no rent will remain in the hands of the logging companies, and there will be little incentive for them to carry out proper forest management. On the other hand, if the logging companies are given too much rent, government income will decrease, thereby lowering the incentive for the government to monitor forest management.

The choice of who is responsible for monitoring logging activities is important as well. If the right to issue logging concessions shifts from the central government to local governments, the rents such as concession fees and tax income will go to the local governments. It is also possible to give the rights to communities as a means to achieve thorough forest management. In Indonesia, traditional community rights for forest resource utilization were stipulated in the 1999 Forestry Act, and with the enactment of the decentralization laws in $1999,{ }^{2}$ local governments

2 The Act No. 22/1999 on Regional Governance and Act No. 25/1999 on Fiscal Balance between the Center and the Regions went into force in January 2001. 
have been allowed to issue small-scale logging concessions. However, the decentralization of power caused problems such as the overlapping of areas for which logging concessions were given and the over-issuing of logging concessions by local governments. It has been shown that even if the authority to issue logging concessions is partially transferred to local governments, in the absence of coordination with the central government, the rent cannot function as an incentive for sustainable forest management.

Forest resource rents in Indonesia were also utilized for the promotion of the plywood industry. This was done by holding down the prices of round wood used by the plywood mills as a policy, thereby transferring the rents of the logging companies to the plywood companies. Thanks to these secured profits, it was expected that the plywood companies would expand their scale and increase their international competitiveness. Concretely, round wood exports were banned in order to keep down the prices for domestic distribution, and logging concessions were given preferentially to companies that had plywood mills, to ensure that the profits arising from the difference between the international and domestic prices would accumulate in the plywood companies as rent.

In debates on industrial policies with respect to the "East Asian experience," such transfer rents are, under certain fixed rules, considered to be economically efficient in the long run as an incentive for technical upgrading and higher management efficiency (Khan 2000). In fact Indonesia succeeded in increasing plywood exports through this policy, transforming the industry into a major earner of foreign currency. However, as a result of the enormous rents accumulated in the industry, the natural resource rent, which essentially should be an incentive for sustainable forest management, functioned contradictorily as an incentive accelerating deforestation by promoting logging activities for the sake of the growth of wood-based industries.

Therefore, in the forestry sector reform carried out by IMF and the World Bank since 1998, transfer rents became a target of criticism, and an attempt was made to have the national government absorb forest resource rents through the resumption of round wood exports and the reform of the logging concession system. How has the distribution of rents changed as a result? Let us now follow the process of forestry sector reform and the change in the distribution of rents between the government and the plywood industry, and examine how they have functioned as an incentive as a result of the institutional reform.

\section{THE DEVELOPMENT OF FOREST-RESOURCE-BASED INDUSTRIES AND DEFORESTATION}

For Indonesia, which possesses the third-largest forest area in the world, with 60 percent of its land covered by forests, forest resources are an important means of 
earning foreign currency. Beginning in the 1960s, the utilization of forest resources was accelerated under the developmentalism of the Soeharto regime, and in the 1970s forest-resource-based industries, which were mainly involved in round wood exports, earned 20 percent of the country's foreign currency income. The harvest rules for round wood were stipulated in the 1967 Forestry Act. The central government gave forest concession rights (hak pengusahaan hutan, HPH) within the production forests to logging operators for a duration of 20 years (with the possibility of a 15-year extension) and allowed them to harvest following selective cutting practices. $^{3}$

The year 1979 was a major turning point for the Indonesian forestry industry. As a means to promote the domestic wood processing industry, HPH holders were obliged to build wood processing mills, and sawmills were obliged to supply their products to the domestic market. In 1981, the government decided to place the plywood industry at the center of the wood processing industry, by adopting a measure to restrict round wood exports to HPH holders possessing or building plywood mills. As a result, HPH holders had to either set up their own plywood mills or sell their concessions to companies that already held processing capability (Araya 1998). Due to these policies to promote the plywood industry, plywood exports reached U.S.\$509 million in 1983, surpassing round wood exports. In 1985, exports of round wood were completely banned, in a move that accelerated exports of plywood. In 1990, the number of plywood mills totaled 132, with an annual production of 10 million cubic meters, and in 1993 the plywood industry gained export income of U.S.\$4.1 billion, accounting for more than 10 percent of total exports (Table I).

The round wood export ban and the measure to link plywood mills and HPH holders provided a mechanism for supplying round wood to plywood mills at a lower price than the international price, resulting in the concentration of HPH holding among a handful of corporate groups with processing capability. By the mid1990s, 10 corporate groups held 228 of the total of 585 HPHs in number; 27 million ha of the national total of 62 million ha in terms of area; and around 40 percent of the total in terms of production. These groups included, among others, the Barito Pacific Group and Bob Hasan Group, which were cronies of President Soeharto, as well as companies whose main shareholders were the national army and police (Brown 1999; Barr 2001).

The Indonesia Plywood Association (Asosiasi Panel Kayu Indonesia, APKINDO) played an important role in the development of the plywood industry. When Mohamed Hasan (commonly known as Bob Hasan) became the president of the association, it launched a policy of stabilizing the plywood price. Its 108 members were divided into seven marketing groups depending on corporate size. The asso-

${ }^{3}$ Under the selective harvest rule, each district is divided into 35 sections, and in each of them, round wood with a diameter not smaller than $50 \mathrm{~cm}$ can be cut in the amount allowed by the government in one year, to be revisited in a 35-year cycle. 
TABLE I

EXPorts of Indonesian Forest Resource Products

\begin{tabular}{rrrrcrc}
\hline Year & Sawn Timber & Plywood & Rattan & Pulp and Paper & Palm Oil & Total Exports \\
\hline 1988 & 811 & 2,092 & 119 & 147 & 324 & 19,215 \\
1989 & 707 & 2,325 & 153 & 199 & 296 & 21,159 \\
1990 & 84 & 2,690 & 275 & 250 & 253 & 25,675 \\
1991 & 90 & 2,772 & 269 & 312 & 335 & 29,142 \\
1992 & 98 & 3,219 & 307 & 401 & 465 & 33,907 \\
1993 & 129 & 4,128 & 333 & 483 & 535 & 36,823 \\
1994 & 166 & 3,650 & 354 & 782 & 878 & 40,053 \\
1995 & 159 & 3,452 & 375 & 1,504 & 973 & 45,418 \\
1996 & 137 & 3,544 & 324 & 1,369 & 1,017 & 49,814 \\
1997 & 112 & 3,477 & 204 & 1,953 & 1,662 & 53,444 \\
1998 & 78 & 2,327 & 11 & 2,469 & 816 & 48,848 \\
1999 & 80 & 2,254 & 16 & 2,646 & 1,170 & 48,665 \\
2000 & 75 & 1,995 & 1 & 3,042 & 1,195 & 62,124 \\
2001 & 88 & 1,656 & - & 2,555 & 1,222 & 56,321 \\
2002 & 115 & 1,507 & - & 2,369 & 2,038 & 57,159 \\
\hline
\end{tabular}

Source: Compiled by the author using data from Bank Indonesia, Indonesian Financial Statistics (various issues).

ciation worked with the Ministry of Industry and Trade, giving export licenses to companies belonging to these groups. The Marketing Committee of the association allocated an export quota to each group and set plywood prices. Thus, through a de facto price cartel, Indonesia gained a dominant position in the world plywood market, gaining a 79 percent share of the world market by the mid-1990s.

The member companies of APKINDO were obliged to pay membership fees to the association, and these funds were utilized by Bob Hasan, the president of the association, as political funds for President Soeharto, thus forming a system under which a part of the rent income accumulated by the plywood companies was returned to Soeharto. The major fees were an export promotion/market expansion fee (U.S.\$7-10 per cubic meter) and an aerial photography fee (U.S.\$2-4 per cubic meter). Furthermore, Bob Hasan preferentially allocated export-related business, such as shipping and insurance, to his group companies and thus made huge profits through plywood exports (Barr 2001, pp. 26-27).

However, partly due to resentment among the major buyers in Japan and the Republic of Korea against APKINDO's price cartel, Indonesia's share in the plywood market began to fall after the mid-1990s (Araya 1998). In 1999, its plywood exports fell to the level of 6 million cubic meters and in 2002 generated revenues of U.S.\$1.5 billion, falling to 2.6 percent of total exports (Table I). It was replaced by pulp and paper as the main forest-resource-based industry. The production total increased from 325,000 tons in 1987 to 4.14 million tons in 2000, consuming 20.28 
million cubic meters of round wood. This amount is larger than the volume consumed for plywood production. ${ }^{4}$

The development of the pulp and paper industry led to an increase in the wood supply from sources other than the HPH system. In 1990, the government issued industrial timber plantation concessions (hak pengusahaan-hutan tanaman industri, HP-HTI ${ }^{5}$ ) for the acceleration of forestation, and also issued timber utilization licenses (izin pemanfaatan kayu, IPK ${ }^{6}$ ) permitting clear cutting in an area in return for turning production forests into timber plantations in order to increase the supply of round wood. While in the 1980s, 25 million cubic meters of round wood were produced annually through HPHs alone, by the mid-1990s the production from HPHs dropped to 17 million cubic meters, with 4.2 million cubic meters being produced from IPKs to compensate for the decrease. IPK production reached 10 million cubic meters in fiscal year 1997/98, while the amount of logging from HPHs dropped to 15.6 million cubic meters. ${ }^{7}$

With this development of industries, the domestic demand for round wood began to surpass by large margins the total amount of round wood officially recorded by the Ministry of Forestry. The government-approved production capacity for industries that had major demand for round wood was as follows (in round wood equivalent terms): sawn timber, 22 million cubic meters; plywood, 19 million cubic meters; pulp, 18 million cubic meters; for a total of 63.5 million cubic meters. Taking the assumption that each industry produces at the approved production capacity level, the comparison of these figures with the total legally sourced volume of 17.2 million cubic meters, based on the internal documents of the Ministry of Forestry in 2000 , leads to the conclusion that most round wood is illegally sourced (Brown 2002a). Furthermore, adding to this the 10 million cubic meters which is assumed to have been smuggled to Malaysia and China, ${ }^{8}$ it can be assumed that more than 75

${ }^{4}$ According to the data of the International Tropical Timber Organization (ITTO), the amount of plywood production in 2000 was 8.2 million cubic meters, which can be converted to the round wood equivalent of 16.4 million cubic meters (the conversion rate for plywood to round wood is 1 : 2).

${ }^{5}$ Business permission for managing an industrial timber plantation with a duration of 30 years. Operators are required to reforest 25 percent of the land. By getting this, clear cutting permission of existing round wood is obtained.

${ }^{6}$ IPK is a permit issued by the central government (or provincial governments) for clear cutting, which is given for the purpose of conversion to plantation or land for transmigration. In principle, issuance for this permit is applied to non-production forests, but often times a permit is given at the same time to convert the natural forest to non-production forest. It is also sometimes issued to convert a harvested production forest site into an industrial timber plantation (hutan tanaman industri, HTI). (According to 1996 SK Dirgen No. 96, conversion to HTI is permitted when the amount of commercial round wood with a diameter larger than $50 \mathrm{~cm}$ is less than 10 cubic meters per ha.) The duration of IPK is one year and since there is no payment of a resource rent fee (provisi sumber daya hutan, PSDH), round wood cheaper than from HPH can be supplied.

7 For figures, refer to Data Strategics Kuhutanan 2002 published by the Ministry of Forestry.

${ }^{8}$ From the trial calculation by Forest Watch Indonesia (FWI) and Global Forest Watch (GFW). 
percent of the round wood produced in Indonesia is illegally sourced. This points to a striking deterioration of forest management governance, which may have resulted in the accelerated deforestation since the latter half of the 1990s. ${ }^{9}$

\section{FORESTRY SECTOR REFORM AFTER THE ECONOMIC CRISIS}

It was the World Bank that initiated forestry reform, following the economic crisis, as a means to counter the accelerated deforestation. In the second IMF Letter of Intent (dated Jan. 15, 1998) of the economic reform program started in 1997, the World Bank launched the reform with a traditional market-oriented approach. The reform aimed at normalizing the market for round wood and plywood through the resumption of round wood exports, removal of the plywood export market monopoly of the APKINDO price cartel, and the delinking of HPHs and plywood mills. The reform was also meant to pave the way solidly for the government, rather than cronies, to collect income from forest resources. The insertion of the reforestation fund, which was previously an off-budget fund used as a source of political funds for President Soeharto, into the general account budget, the introduction of a public tender system for HPH issuance and performance bonds, ${ }^{10}$ and a raise in royalties were proposed.

As a result, in April 1998 the export tax for round wood exports was reduced sharply and exports were resumed. By the end of 1998, the preferential issuance of logging concessions to companies with plywood mills was stopped, and the market intervention by APKINDO through the export quota system was eliminated. It was decided to transfer the reforestation fund to the general account budget, and the levied money, which had been called a royalty, now became a forest resource utilization fee (provisi sumber daya hutan, PSDH, hereinafter "resource rent fee") to be collected in accordance with the amount of round wood harvested. The rate was set at 6 percent of the market round wood price. ${ }^{11}$

In the Policy Reform Support Loan (PRSL) of the World Bank, issued in April 1998 , in addition to the above-mentioned reform plans, it was agreed to complete the reform of the logging concession system, including that of the role of the community in forest management, by the end of 1998. In addition, a request was made that a moratorium be imposed on land usage conversion from production forest into

${ }^{9}$ According to the Ministry of Forestry, the speed of the deforestation, which was $0.6-1.2$ million ha per year from 1970 to 1990, accelerated to 1.7 million ha per year from 1986 to 1997, 2-3 million ha per year on and after 1999, and the remaining forest area was 104.98 million ha in 2000.

10 The deposit paid by logging companies before harvesting is returned with interest when logging is done following the legal rules, but is confiscated as a fine when a violation of logging rules is found. It thus function as an incentive for the observance of logging rules.

11 The income gained by the government through issuing logging concessions includes, in addition to the forest-based business permission fee (U.S.\$3-10/ha), a reforestation fund (dana reboisasi, DR), and PSDH collected in accordance with the amount harvested. 
agricultural or timber plantations until the completion of the above reform. However, as there were delays in introducing the public tender system, the performance bonds, and the moratorium on land usage conversion, the World Bank suspended the second loan of the first phase of PRSL in December 1998. Following this pressure, the public tender system for the issuance of HPH was finally introduced in April 1999, but the performance bonds were never introduced.

After President Soeharto stepped down in May 1998, a new idea, influenced by the arguments of Indonesian NGOs, Islamic groups, and discussions at universities, was incorporated into the reform plan of the World Bank, which had previously been biased in favor of economic efficiency. Minister of Forestry and Plantation Muslimin Nasution, a member of an Islamic political party, insisted on the necessity of redistributing forestry resources from the point of view of social justice, and advocated a reform that would place limits on the possession of logging concessions by private companies, promoting in their place cooperative ownership. In June 1998, a reform committee was established including NGOs and universities, and a reform plan which considered the rights of communities and decentralization was put forward (Seymour and Kartodihardjo 2000, pp. 96-99). In the second phase of PRSL, starting in May 1999, a proposal was made to value traditional community rights in accordance with customary law, and the principal of community involvement in forest management and the assurance of transparency in the process of concession issuance were stipulated in the new Forestry Act (Act No. 41/1999).

Following the IMF/World Bank reform, the Indonesian government pushed through a reform of the logging concession issuance system in relation to decentralization. In 1999, it promulgated Government Regulation (No. 6/1999) which gave regents (bupati) the authority to grant, to individuals and cooperatives, forest products collection rights (hak pemungutan hasil hutan, $\mathrm{HPHH}$ ), involving permission to collect forest products in a forest area not greater than 100 ha for a period of one year, along with timber utilization and collection licenses (izin pemungutan dan pemanfaatan kayu, IPPK), which were, like IPKs, permissions to clear cut standing timber during the conversion of land usage. ${ }^{12}$ In some areas, the regent might also now give a small-scale logging concession (HPH-Kecil) allowing selective cutting in an area not greater than 50,000 ha for a period of 20 years. With the agreement of the HPH-holding company, the regent could grant a permission for selective cutting within a HPH production forest. Although the central government does not have a grasp of the exact number of various types of permits granted

12 The area was up to 100 ha and the duration one year. The regency government could impose a forest resource utilization tax in addition to the levy imposed by the central government for logging activities, and this was utilized by local governments as a financial source. According to 2003 research conducted by the author in Kutai Barat regent, East Kalimantan, out of the total revenue of 400 billion rupiahs in the 2002 budget of the regent, 16 billion rupiahs was income gained by issuing IPPK. 
in different regencies, it is assumed that more than two thousand permits have been issued. ${ }^{13}$

In accordance with the 1999 Forestry Act, the authority to issue HPHs was partly transferred to the provinces. Areas between 10,000 ha and 50,000 ha would be under the authority of the Minister of Forestry, but areas not greater than 10,000 ha now fell under the authority of the provincial governor. Moreover, in order to eliminate the concentration of HPH holdings, limits were introduced: each concession area could be up to 50,000 ha; one group could hold up to 100,000 ha in a single province and up to a total of 400,000 ha throughout the country. Prior to the enactment of the new Forestry Act, the 1998 ministerial ordinance had already contained a stipulation allocating 10 percent of new logging concessions to cooperatives, with the final future goal being 20 percent, as a means to increase HPH holding by stateor province-managed enterprises and cooperatives..$^{14}$ Also, a regulation was considered which would preferentially allocate concessions with areas not greater than 10,000 ha issued by provinces to the cooperatives. As a result, a structure emerged where not only the central government and large corporations, but also new actors such as provincial governments, regency governments, and cooperatives could hold a share of the forestry resource rent. However, many cooperatives have close ties with provincial governments, the military, or politicians, and in many cases they are used as new means to collect political funds (Brown 1999, pp. 54-59).

Despite the various institutional reforms, the ongoing deforestation and rampant illegal logging continued, and it became inevitable that a fundamental change would be made to the direction of reforms after 2000. Round wood exports were resumed as a first step of the World Bank-led reform after the economic crisis. The round wood export tax was cut from 200 to 30 percent in 1998, but a plan to reduce it further to 10 percent was not realized, and exports failed to show vigorous growth, due to the licensing system and strong resistance by APKINDO. The plywood industry insisted that opening the door to round wood exports at a time when there was a shortage of round wood in the domestic market would result in an outflow of round wood to Malaysia and to rampant illegal logging inside the country. It also claimed that plywood production was just 20 million cubic meters in 2000, less than one-third of the production capacity of the plants, due to the shortage of round wood caused by the resumption of exports (ITTO, various issues). Moreover, even after the resumption of exports, the gap between domestic and international prices of round wood failed to narrow and it became difficult to control illegal exports. Therefore, the government made a decision to reverse the policy and reimposed the export ban with a duration of six months following a joint ministerial decree from

${ }^{13}$ From an interview conducted at the Ministry of Forestry in August 2003. According to research in Kutai Barat regent, the regent had issued 341 HPHH by 2002.

14 Stipulated in Decree of the Minister of Forestry and Plantation No. 732, 1998 (Kumenhutbun No. 732/1998). 
the Ministry of Forestry and the Ministry of Industry and Trade issued on October 8, 2001 (put into effect October 31). The ban was later extended indefinitely.

The decentralization of the forest management system, which had been ongoing since 1999, also faced a policy reversal. Government Regulation No. 34, promulgated in June 2002, banned the issuance of logging concessions by regents, reversing Government Regulation No. 6/1999, and nullified all licenses issued since January 2002 ${ }^{15}$ Government Regulation No. 34 also changed the supervisory authority over plywood and pulp industry operations from the Ministry of Industry and Trade to the Ministry of Forestry, with the aim to establish a system where the supply and demand of raw timber would be overseen and adjusted in an integrated way. Until then, the permit for production plant capacity, constituting the demand side for round wood, had been granted by the Ministry of Industry and Trade, and the amount of cutting had been supervised by the Ministry of Forestry through annual activity reports submitted by each plant. However, because only plants consuming more than 6,000 cubic meters of round wood per year were obliged to submit reports, and worse, as only half of those actually submitted reports, it had been impossible for the Ministry of Forestry to grasp the origin of the supply of raw timber in detail (Brown 2002a, p. 10). Therefore, the reform was significant in terms of setting controls for the sustainable amount of logging and timber distribution, and also meant a major policy change from the World Bank reform that relied totally on the supply side.

In December 2002, the Wood Industry Revitalization Agency (Badan Revitalisasi Industri Kuhutananan, BRIK) was established under a joint ministerial decree of the Ministry of Forestry and Ministry of Industry and Trade. The purpose was to secure a legal supply of raw timber for the industry, to make sustainable forest management possible by cutting the supply route of illegal logs, and to revitalize the industry in the long term. Therefore, the top positions in the agency were dominated by persons from the sawn timber association, plywood association, etc. The system they introduced was to oblige traders to obtain a registered wood products exporter certificate (eksportir terdaftar produk indsutri kuhutanan, ETPIK) issued by the Ministry of Forestry and the Ministry of Industry and Trade when exporting plywood, sawn timber, and furniture. The task of BRIK was to collect the documents necessary for certification-documentation of stock in all processes from timber to finished products, wood mutation report (laporan mutasi kayu, LMK), and forest products legal certification letter (surat keterangan sahuya hasil hutan, SKSHH) at the distribution stage - and to make recommendations regarding ETPIK certification to the Ministry of Forestry and the Ministry of Industry and Trade. In July 2003, 3,794 companies filed applications and 3,588 companies obtained

15 Kutai Barat regent stopped issuing IPPK voluntarily in December 2001 and HPPH in June 2002. However, as the HPH-Kecil issued to 12 corporations have a 20 -year duration, they continue to be effective. 
certificates. Although this refined system was established, voices have emerged among foreign aid organizations and other groups questioning whether a selfcertification system led by business groups can be effective in stopping the circulation of illegal logs.

Through this system, the Ministry of Forestry returned control over the logging concessions, which had been partly given to regency governments, back to the center again and formed a system of cooperation between the central government and the business groups, with BRIK playing an important role in the export permit certification process. This structure is ironically quite similar to the relation between the central government and APKINDO under the Soeharto regime, which was the main target of the reform since 1998.

\section{CHANGE OF THE RESOURCE RENT DISTRIBUTION}

\section{A. Institutional Reform and Rent Flows}

Although we examined various institutional reforms since 1998 in detail in the last section, we will now discuss how rent flowed through the institutional changes and in whose hands it accumulated, from the point of the resource rent distribution. Figure 1 shows rent flows under the Soeharto regime before the reforms. As explained in Section III, under this structure, through the round wood export ban and the linkage between plywood mills and HPH, cheap round wood was supplied to plywood companies and the export price was raised through APKINDO's price cartel. This led to the accumulation of rent in the plywood industry. Part of the rents collected at plywood companies was absorbed as association fees levied by APKINDO and passed on to President Soeharto as political funds. The rents distributed to the plywood industry functioned as an incentive for the development of the industry, accelerating logging activities. However, as President Soeharto and the government also accumulated sufficient rents, they also functioned as an incentive to carry out proper supervision in order to maintain the forest logging concession management system, with the result being that illegal logging activities were prevented.

However, IMF and the World Bank insisted that the accumulation of rent by the industry was inefficient and promoted institutional reform, abolishing the plywood price cartel and closing the gap between the domestic and international price of round wood. By reimposing round wood exports and raising the logging concession fee and resource rent fee, they tried to stop the opaque flow of money accumulated in the plywood industry and its partial utilization as political funds for President Soeharto. At the same time, they tried to promote the decentralization of power and distribute the rent, which had been captured by the central government, to local governments, thereby giving them an incentive for sustainable forest management. 
Fig. 1. Rent Flow during the Plywood Industry Fostering Period under the Soeharto Regime

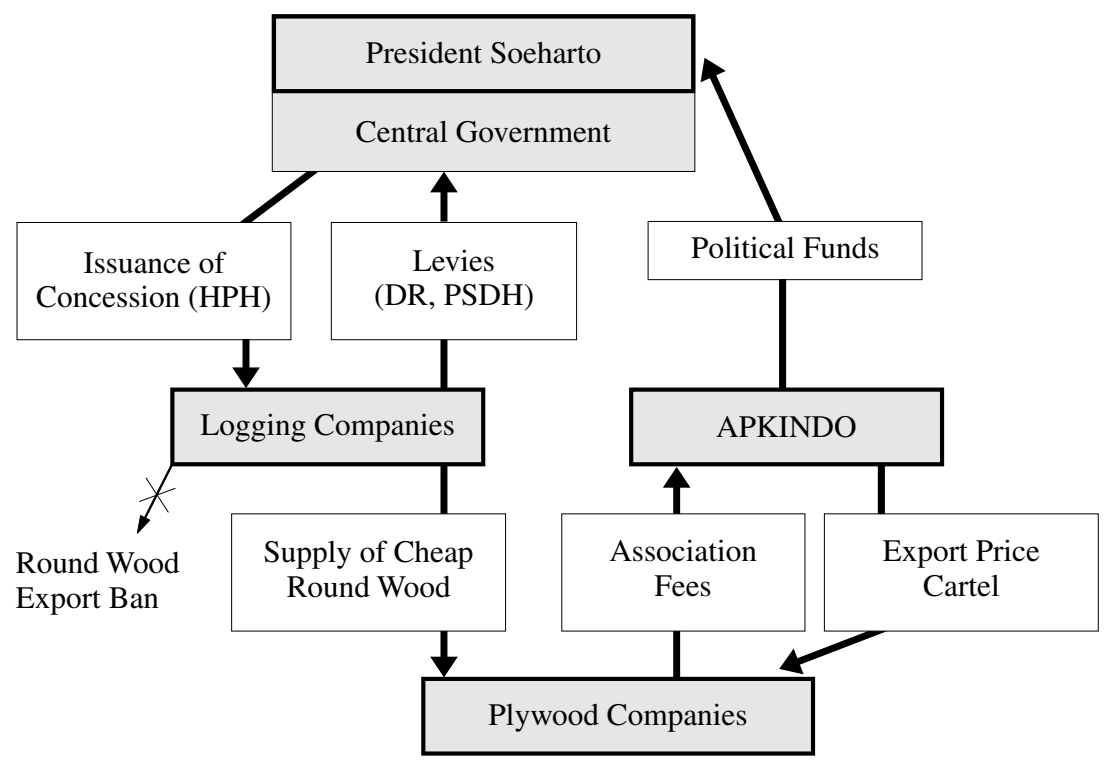

Source: By the author.

Note: Shaded boxes signify major actors receiving rents. Arrows signify the flow of the rent.

Fig. 2. Ideal Structure of IMF/World Bank Reform

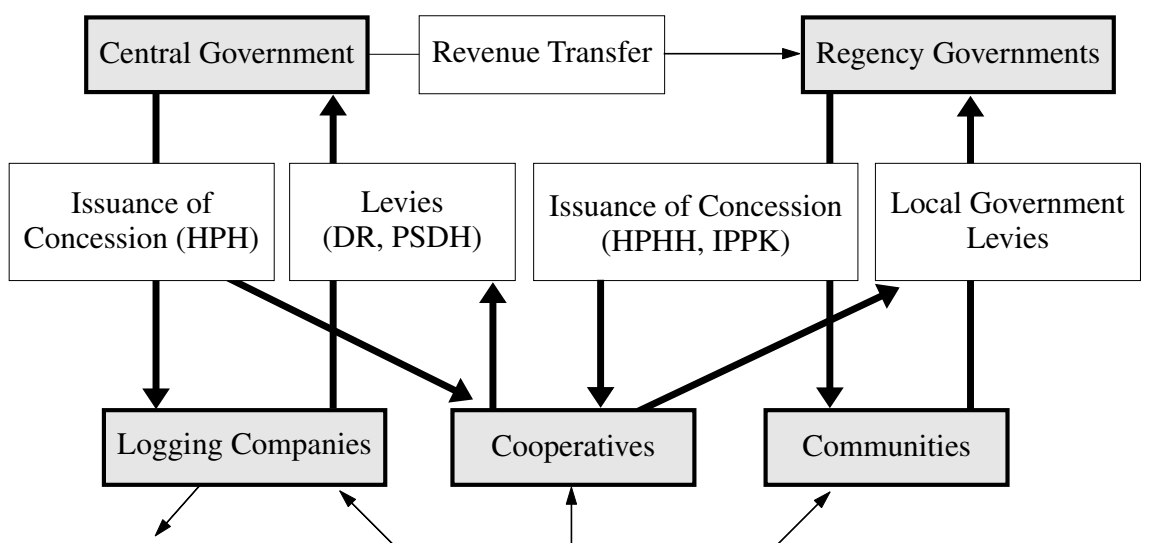

Lifting of Round

Wood Export Ban

Supply at the Market Price: Rent Not Generated

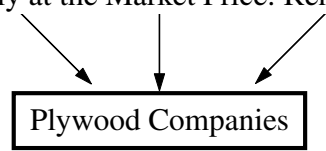

Source: By the author.

Note: Thick arrows signify rent flows, and shaded boxes major actors receiving rents. As round wood is supplied to plywood companies at the market price, no rent is transferred. 
Fig. 3. Rent Flows after the Resignation of Soeharto

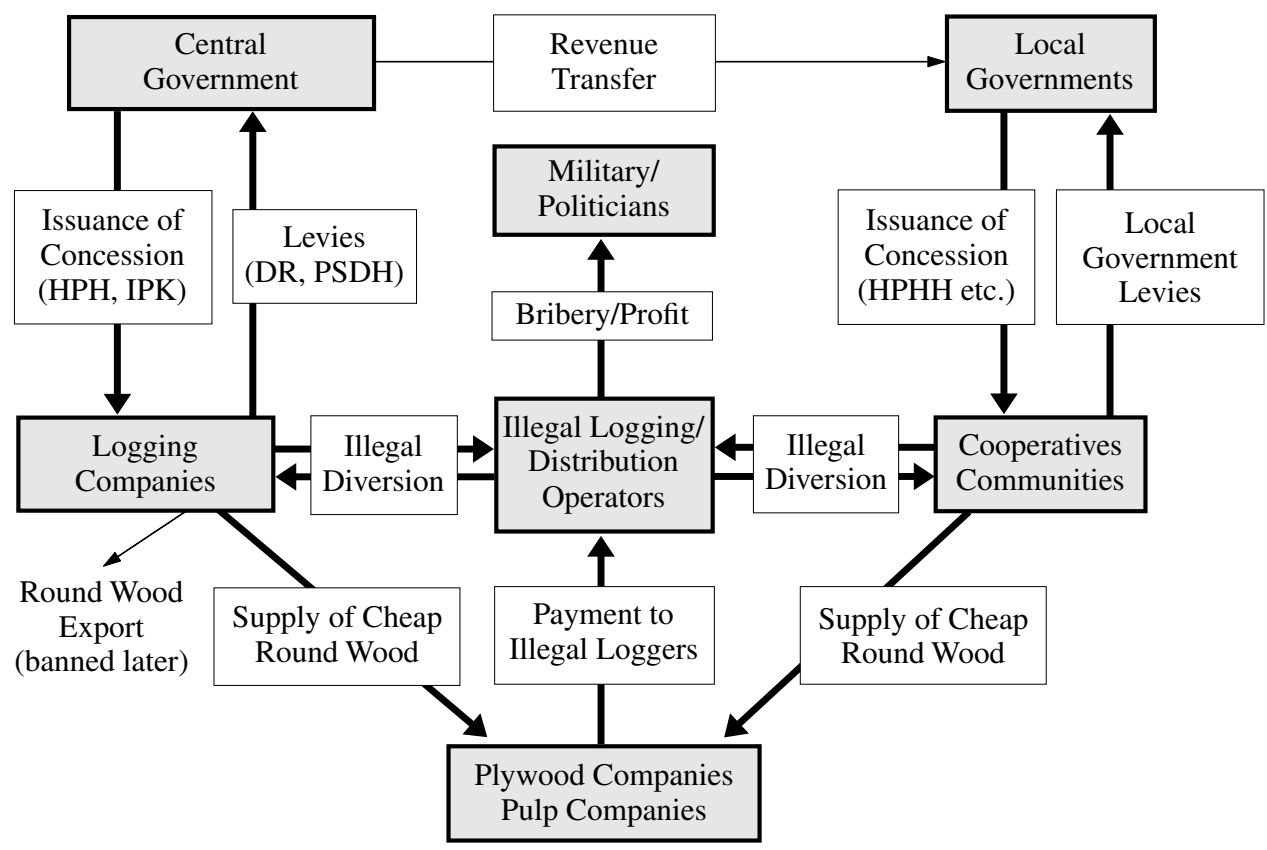

Source: By the author.

Note: Thick arrows signify rent flows and shaded boxes major absorbers of rent. Consumption of round wood not only by plywood companies but also by pulp companies increased. Legal exports of round wood were done only temporarily, while log smuggling was going on constantly. Through illegal diversions, not only illegal operators, but also logging companies became able to accumulate rents by avoiding payments of taxes and fees.

The ideal rent flow as envisaged by the reform is shown in Figure 2. Here, the flow of rent to the plywood companies disappears together with the flow through APKINDO that was turned into political funds, and it is guaranteed that the rent can be absorbed by the government from logging companies, cooperatives, and communities.

However, in the actual reform, neither the raising of the resource rent fee nor the introduction of performance bonds was adequate, and the government could not absorb the rent properly. Further, round wood exports were banned again, and the plywood and pulp companies were able to accumulate rent by receiving a cheap supply of round wood, either illegal or legal, as before. On the other hand, a structure was formed under which logging companies and communities avoided paying the resource rent fee to the government by selling round wood in the illegal market, thus accumulating rent (Figure 3). As discussed in Section III, since the plywood 
companies and pulp plants receive a supply of round wood from the illegal market, the rent absorbed by people engaged in illegal logging and distribution is greater than that absorbed legally by the government and logging companies, and a portion is also captured by military officers and politicians who receive bribes for merely closing their eyes to illegal activities.

According to Scotland (1998), who calculated how the rent accumulated by logging companies actually changed between the periods before and after the economic crisis, the excess profit (rent) dropped from 7.6 percent before the crisis to 3.5 percent after the crisis began. Furthermore, based on Scotland's study, Barr (2001, pp. 50-52) argures that the decrease of the profit rate was serious for smalland medium-scale HPH holding companies, and it can be assumed that the weakening of the business basis is one factor which encouraged illegal logging activities. Thus, the fact that the rent accumulated in the hands of the logging companies decreased through the economic crisis shows that there was a structural change in the rent distribution, where rents that were once captured by logging companies and transferred to the plywood industry flowed into the hands of other entities.

\section{B. International and Domestic Prices of Round Wood and the Rents of Plywood Companies}

How did the gap between the international and domestic prices of round wood, which was criticized as producing rents for the plywood industry, actually change throughout the institutional changes such as the resumption of round wood exports and the raise in the resource rent fee? Figure 4 shows trends in the price of round wood after the economic crisis, using ITTO data. Between 1993 and 1994, the round wood price in Southeast Asia experienced instability because of the fear about the shortage of round wood on the international market due to factors such as the export ban in Saba, Malaysia. It then began to rise from the end of 1995 and reached U.S.\$250 in the first half of 1996. However, it dropped to around U.S.\$200 in 1997 and then plunged at the beginning of the Asian currency crisis. We will take the price of meranti of Sarawak, Malaysia as the international price and the price of meranti for plywood production (inner material of plywood) in Indonesia as the domestic price for our discussion here. ${ }^{16}$ The international price, which dropped from 1998 to 1999, rose after that time until 2000 and stabilized around U.S.\$155, but dropped again to U.S.\$120-130 at the end of 2001. In 2002, under the effect of the restoration of the round wood export ban in Indonesia at the end of 2001, the upward pressure on prices was intensified, and the price returned to a level between U.S. $\$ 150$ and 160 .

Looking at the domestic price of round wood for plywood, it fluctuated from 1998 to mid-2001, moving along with the international price so the gap between

16 Price data extracted from ITTO's Tropical Timber Market Report, issues 1998/1-2004/1. 
Fig. 4. Gap of International/Domestic Prices of Round Wood for Plywood

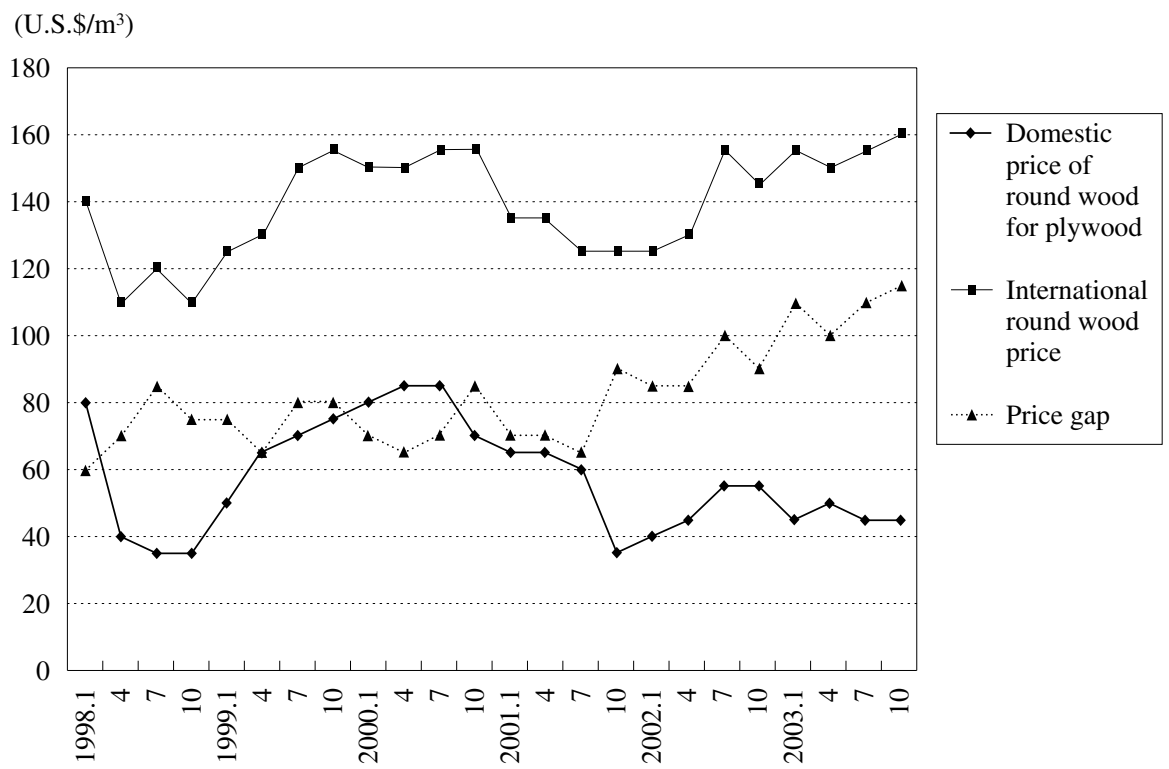

Source: By the author using data obtained from ITTO (various issues).

Note: The price of meranti of Sarawak is taken as the international price of round wood. The Indonesian market price of meranti for the inner material of plywood is taken as the domestic price of round wood for plywood.

the two remained stable at around U.S.\$60-80. However, in contrast to the international price, which rose steadily from the latter half of 2001 , the domestic price continued to drop, resulting in a widening of the gap between the international and domestic prices until it topped U.S.\$80 in 2002, and U.S.\$100 in 2003 (Figure 4). The cause for this widening between the domestic and international prices of round wood, contrary to the policy intention, seems to be the reinstitution of the round wood export ban. The resumption of round wood exports in 1998 hardly achieved the goal of narrowing the price gap. It can be assumed that this happened because exports failed to expand greatly until 1999, since APKINDO opposed the round wood exports using the domestic shortage of round wood supply as a pretext, and since exports were on a permission basis. Later, although round wood exports increased sharply in 2000, the increase was not sufficient to close the price gap. Moreover, with the reimposition of the export ban in October 2001, the domestic price dropped and the gap with the international price actually widened.

What changes happened with respect to the rent accumulation in the plywood industry through the reforms following the crisis in the changing market environment of round wood? Let us now proceed with our discussion, using the rent calcu- 
lation formula proposed by Brown (1999). In it, rent is defined as the difference gained by subtracting the total cost from the plywood export price (free on board, FOB). The total cost includes production costs such as labor costs, fuel costs, machinery costs, etc. as well as association fees paid to APKINDO and office costs, including necessary fees for export promotion and market expansion (referred to as marketing fees in this paper), depreciation, and interest payments. Assuming an exchange rate of $\operatorname{Rp} 2,350$ to the U.S. dollar before the crisis and $\mathrm{Rp} 8,000$ after the crisis, and adding an increase of 15 percent in labor costs, 45 percent in fuel costs, and 300 percent in the import price for capital goods such as machinery and glue following the crisis into the cost calculation, the rent captured by the plywood companies for 1996 before the economic crisis turns out to be U.S.\$25.19 per cubic meter of plywood and U.S.\$12.59 per cubic meter of round wood. In December 1998, after the economic crisis, given the absence of the fee collection of APKINDO, the rent that remained in the plywood companies increased greatly from the period before the crisis, reaching U.S. $\$ 80$ per cubic meter of plywood (U.S.\$40 per cubic meter of round wood) (Table II).

However, the analysis by Brown (1999) does not examine trends in the rent after the resumption of round wood export, so here, we calculate the amount of the rent of the plywood industry for each three-month period after 1998 using the ITTO data on plywood and round wood prices together with the factory costs, office costs, and exchange rate of 1998 after the crisis, as assumed by Brown, fixed as they were (Figure 5). According to this calculation, the rent continued to rise from 1998 to the end of 1999, reaching U.S.\$122 per cubic meter of plywood and U.S.\$61 per cubic meter of round wood. After that, however, it dropped sharply, falling below zero in April 2001. Then although it rose steadily to reach U.S. $\$ 42$ per cubic meter of plywood and U.S.\$21 per cubic meter of round wood at the end of 2003, this was still less than half of the figure in 1999. In this calculation, the exchange rate, labor costs, and fuel costs after 1998 are fixed, but since in reality both labor costs and fuel costs rose, and the exchange rate was over Rp 10,000 to the U.S. dollar, the actual cost would be more than that assumed in this calculation and the rent of the plywood industry even lower than the above figures.

As mentioned above, the gap between the international and domestic prices of round wood widened from the latter half of 2001, but the rent of the plywood industry fell by more than half from 2001 compared to 1999 . This is contrary to the commonly stated argument that the plywood industry would accumulate rent from the cheap supply of round wood. Why was a structure formed where the rent would not be allotted to the plywood industry despite the cheap supply of round wood shown in the price gap between the international and domestic market? The influence of the international plywood market environment must be carefully examined here. In 1996, Indonesian plywood was traded at a high price of U.S. $\$ 500(2.7 \mathrm{~mm})$ per cubic meter under the control of APKINDO, but by mid-1988 this price fell to 
TABLE II

Captured Rent of Plywood Companies

Source: Compiled by the author based on Brown (1999, p. 66, Table 6.4).

Notes: 1. It is assumed that labor costs rose by $15 \%$ after the crisis.

2. It is assumed that import costs for glue, machinery, etc. increased by $300 \%$ due to the depreciation of the exchange rate, and that one-fifth of additional raw materials were imported.

3. It is assumed that fuel costs rose by $45 \%$ after the crisis.

4. After the crisis the APKINDO association fee decreased to 0 and the marketing fee dropped to U.S.\$8.29.

5. The depreciation is for 15 years assuming machines at the cost of U.S. $\$ 26.50$ million, which produce 80,000 cubic meters of plywood per year.

6. It is assumed that the interest is half of the cost of machines, and that U.S.\$13.25 million is paid for through a dollar loan that charges $12 \%$ interest.

7. The exchange rate is assumed to be U.S. $\$ 1=\operatorname{Rp} 2,350$, and U.S. $\$ 1=\operatorname{Rp} 8,000$ after 1998.

8. The production cost after 1999 is fixed without taking the effect of the exchange rate fluctuation into consideration.

9. The round wood necessary for the production of one cubic meter of plywood is assumed to be two cubic meters.

10. Rent for plywood = plywood FOB price - round wood price (two cubic meters) total cost in U.S. dollars.

11. For variables (1) and (2), the data from 1998 to 2003 were used from ITTO (various issues).

12. For variable (1), the domestic price of meranti (inner material) for plywood is used.

13. Variable (3) = variable (2) - variable (1) - total cost in U.S. dollars. 
Fig. 5. Rents of the Plywood Industry

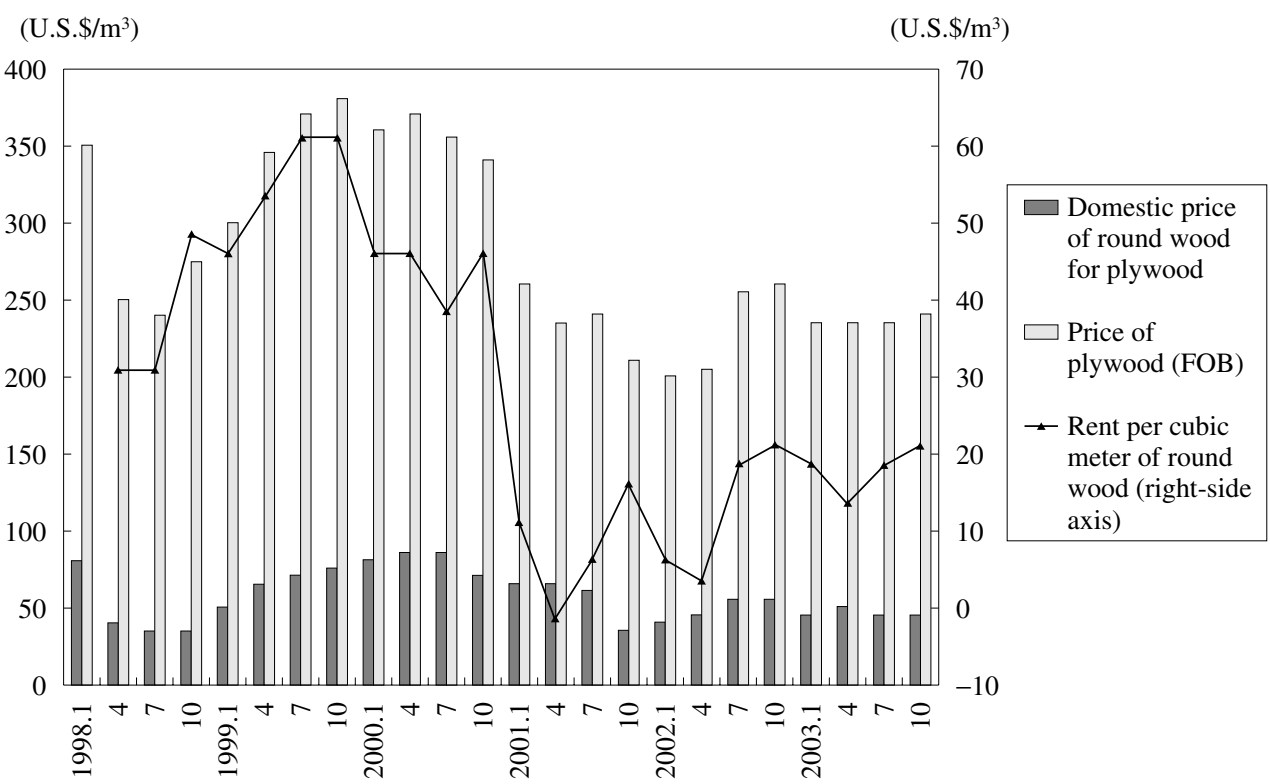

Source: By the author using data obtained from ITTO (various issues).

Note: The domestic price of meranti for the inner material of plywood is used here as the domestic price of round wood for plywood. For the plywood price, the export price (FOB) of $2.7 \mathrm{~mm}$ plywood is used. Assuming: rent for plywood = plywood price (price of round wood for plywood per cubic meter $\times 2$ ) - fixed cost; the rent per cubic meter of round wood is one half the value of the rent per cubic meter of plywood.

U.S.\$233 with the Asian currency crisis and the depreciation of the yen. However, from the end of 1998, growing demand in China and the stronger yen resulted in a price recovery, to U.S.\$371 at the end of 1999. After 2001, however, the market soured considerably due to the change of Chinese duties in favor of round wood imports in 2001, the intensified competition with wooden products other than plywood, and the depression in the construction sector in Japan, Korea, and Germany. The price fell to U.S.\$209 in March 2002. This low price may be partly due to the fact that the removal of the Indonesian round wood export ban caused a great quantity of round wood to flow to China and Malaysia, resulting in falling demand for Indonesian plywood in China and strengthened competitiveness for Malaysian plywood. Later in 2002, the plywood price recovered slightly, seemingly as the result of the reinstitution of the round wood export ban by Indonesia. At the same time, the export ban led to a shortage of round wood in Malaysia and an increase in plywood imports by China. Thus, it can be said that the round wood export ban and the international plywood market trends surrounding it had a significant influence on the decrease of the rent captured by the plywood industry. 


\section{CONCLUSION}

The forestry sector reform promoted by IMF and the World Bank to cope with the proceeding deforestation and rampant illegal logging after the economic crisis aimed to correct the distortion of the round wood market caused by the plywood industry promotion policy under the Soeharto regime, and to legally return the enormous forest resource rents out of the hands of Soeharto cronies and back into the hands of the government. For that purpose, the resumption of round wood exports, the raising of logging royalties, and the measures to abolish the link between HPHs and the plywood mills and the price cartel by APKINDO, represented an attempt to close the price gap between the domestic and international round wood market and to absorb the rent into the government. However, these reforms did not move forward as hoped for due to intensive resistance by the plywood companies. The raising of the resource rent fee, the introduction of performance bonds, and even round wood exports did not proceed as planned. In a situation where illegal logging and smuggling were not curtailed, a policy reversal in the form of the reinstitution of the round wood export ban had to be made.

On the other hand, the reform of the concession system promoted by the Ministry of Forestry in the midst of the process of decentralizing power was also haphazard. In 1999, the right to issue concessions was given to regents and the forest resource rent, which had been centrally controlled, was partly given to local governments and communities as a means to raise the incentive for sustainable forest management. Contrary to idealistic expectations, however, the overissue of concessions by regents in local areas led to confusion in forestry management work, providing opportunities for illegal logging. The Ministry of Forestry then reversed its policy and launched an integrated forest management policy, reclaiming the right to issue concessions, which was once given to the local governments, and transferring forest-resource-based industries, such as the plywood and pulp industries, from the jurisdiction of the Ministry of Industry and Trade to the Ministry of Forestry. At the same time, the Ministry of Forestry built a cooperative relation with BRIK, a new body led by business groups, with the aim of expelling illegal round wood from the demand. This close relationship, however, turned out to be a similar structure to the Soeharto era where the central government controlled the rent through a centralized management, sharing it with particular business groups.

While the World Bank and the Ministry of Forestry were confused over the correct direction of reforms, the enormous rents being accumulated by the plywood industry fell by half from 1998 to 2003. This was not, however, because the government absorbed the rent by closing the gap between the international and domestic prices of round wood and because of the raising of the resource rent fee, as intended by the World Bank. Rather, although the price gap widened as a result of the 
reinstitution of the round wood export ban, the plywood industry was not able to accumulate the rents in its hands due to the recession of the international plywood market, and worse, it was obliged to chase cheaper round wood through illegal supply sources in order to continue its operations. In the meantime, the rent flowed overseas or to the illegal market and fell into the hands of those involved in illegal logging and transactions, or of military officers and government officials who were bribed to overlook illegal activities. Thus, although in the midst of institutional reform after the crisis, the recipients of the forest resource rent did actually change, in the final analysis an efficient distribution of rent, where the rent could play the function of an incentive for sustainable forest management, was not achieved. Needed policies include not only the reform of the supply side of round wood, through measures such as strengthening the monitoring system to crack down on illegal round wood circulation, but also more proactive intervention by the government with an emphasis on the demand side of round wood. Measures such as the downsizing of the forest resource based industry, which over-consumes forest resources, should be thoroughly considered.

\section{REFERENCES}

Araya, Akihiko. 1998. Indoneshia gōhan sangyō: Sono hatten to sekai paneru sangyō no kongo [Plywood industry in Indonesia]. Tokyo: Nihon Ringyō Chōsakai.

Ascher, William. 1999. Why Governments Waste Natural Resources: Policy Failures in Developing Countries. Baltimore, Md.: Johns Hopkins University Press.

Barr, Christopher. 2001. Banking on Sustainability: Structural Adjustment and Forestry Reform in Post-Suharto Indonesia. Washington, D.C.: WWF Macroeconomics Program Office; Bogor: Center for International Forestry Research.

Brown, David W. 1999. Addicted to Rent: Corporate and Spatial Distribution of Forest Resources in Indonesia; Implications for Forest Sustainability and Government Policy. Jakarta: UK Department for International Development / Indonesia-UK Tropical Forestry Management Programme.

- 2002a. "Analysis of Timber Supply and Demand in Indonesia." Paper prepared for World Wide Fund for Nature (WWF) and the World Bank.

- 2002b. "Regulation, Law and Illegal Logging in Indonesia." Paper prepared for WWF and the World Bank.

Casson, Anne. 2001. Decentralisation of Policies Affecting Forests and Estate Crops in Kutai Barat District, East Kalimantan. Bogor: Center for International Forestry Research.

Dermawan, Ahmad, and Ida Aju Pradnja Resosudarmo. 2002. "Forests and Regional Autonomy: The Challenge of Sharing the Profits and Pains." In Which Way Forward? People, Forests, and Policymaking in Indonesia, ed. Carol J. Pierce Colfer and Ida Aju Pradnja Resosudarmo. Washington, D.C.: Resources for the Future (RFF); Bogor: Center for International Forestry Research (CIFOR); Singapore: Institute of Southeast Asian Studies (ISEAS).

Dudley, Richard G. 2002. "Dynamics of Illegal Logging in Indonesia.” In Which Way Forward? People, Forests, and Policymaking in Indonesia, ed. Carol J. Pierce Colfer and 
Ida Aju Pradnja Resosudarmo. Washington, D.C.: RFF; Bogor: CIFOR; Singapore: ISEAS.

Holmes, Derek. 2000. Deforestation in Indonesia: A Review of the Situation in 1999. Jakarta: World Bank.

International Tropical Timber Organization (ITTO). Various issues. Tropical Timber Market Report. Yokohama: ITTO.

Kartodihardjo, Hariadi. 2002. "Structural Problems in Implementing New Forestry Policies." In Which Way Forward? People, Forests, and Policymaking in Indonesia, ed. Carol J. Pierce Colfer and Ida Aju Pradnja Resosudarmo. Washington, D.C.: RFF; Bogor: CIFOR; Singapore: ISEAS.

Khan, Mushtaq H. 2000. "Rents, Efficiency and Growth." In Rents, Rent-Seeking and Economic Development: Theory and Evidence in Asia, ed. Mushtaq H. Khan and Jomo Kwame Sundram. Cambridge: Cambridge University Press.

McCarthy, John F. 2000. "The Changing Regime: Forest Property and Reformasi in Indonesia." Development and Change 31, no. 1: 91-129.

Obidzinski, Krystof, and Iman Suramenggala. 2000. "Illegal Logging in East Kalimantan: Papers on Social, Economic and Political Implications.” Paper prepared for Forest Products and People Program. Bogor: Center for International Forestry Research; Yokohama: International Tropical Timber Organization; Jakarta: Berau Forest Management Project.

Ostrom, Elinor. 1990. Governing the Commons: The Evolution of Institutions for Collective Action. Cambridge: Cambridge University Press.

Scotland, Neil. 1998. "The Impact of the Southeast Asian Monetary Crisis on Indonesian Forest Concessions and Implications for the Future.” ODA-Department for International Development Report no. SMAT/EC/98/02. Jakarta: Indonesia-UK Tropical Forestry Management Programme.

Seymour, Frances J., and Hariadi Kartodihardjo. 2000. "Indonesia.” In The Right Conditions: The World Bank, Structural Adjustment, and Forest Policy Reform, ed. Frances J. Seymour and Navroz K. Dubash. Washington, D.C.: World Resources Institute. 